\title{
Principles of Ocular Pharmacology
}

\author{
Yong Park, Dorette Ellis, Brett Mueller, Dorota Stankowska, \\ and Thomas Yorio
}

\section{Contents}

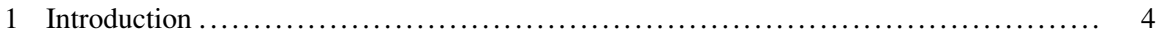

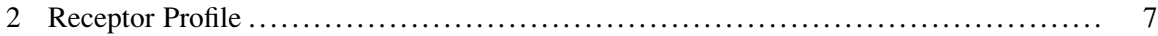

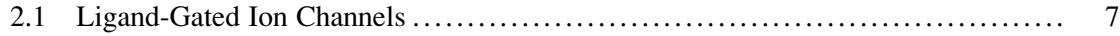

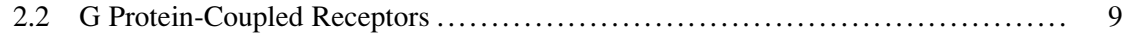

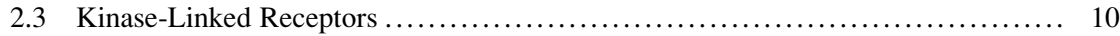

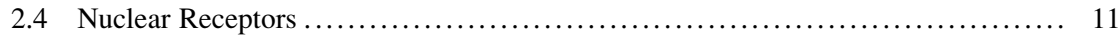

3 Drug Receptor Targets as Modulators of Ocular Function ......................... 12

3.1 Ion Channel ...................................................... 12

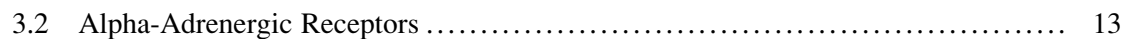

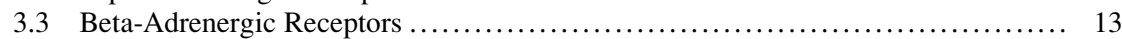

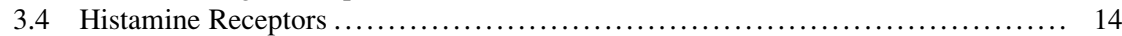

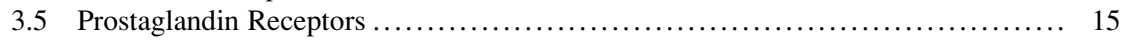

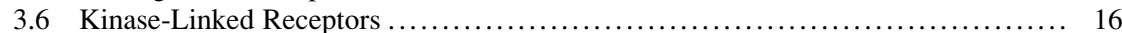

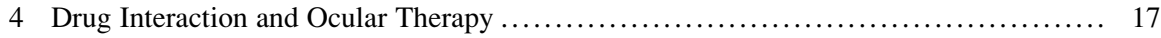

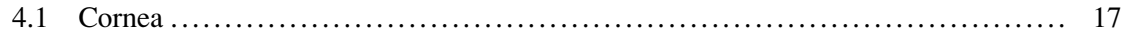

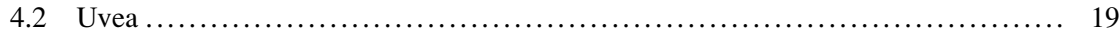

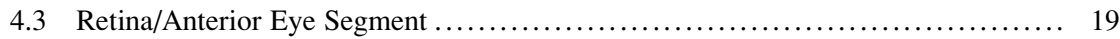

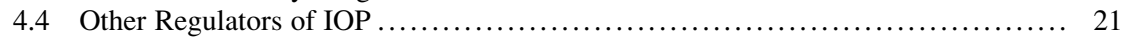

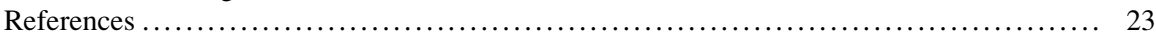

\begin{abstract}
Recently, in a poll by Research America, a significant number of individuals placed losing their eyesight as having the greatest impact on their lives more so than other conditions, such as limb loss or memory loss. When they were also
\end{abstract}

Y. Park • D. Ellis • D. Stankowska • T. Yorio $(\triangle)$

North Texas Eye Research Institute, University of North Texas Health Science Center, Fort Worth, TX, USA

e-mail: Thomas.Yorio@unthsc.edu

B. Mueller

Department of Ophthalmology, University of Louisville, Louisville, KY, USA 
asked to rank which is the worst disease that could happen to them, blindness was ranked first by African-Americans and second by Caucasians, Hispanics, and Asians. Therefore, understanding the mechanisms of disease progression in the eye is extremely important if we want to make a difference in people's lives. In addition, developing treatment programs for these various diseases that could affect our eyesight is also critical. One of the most effective treatments we have is in the development of specific drugs that can be used to target various components of the mechanisms that lead to ocular disease. Understanding basic principles of the pharmacology of the eye is important if one seeks to develop effective treatments. As our population ages, the incidence of devastating eye diseases increases. It has been estimated that more than 65 million people suffer from glaucoma worldwide (Quigley and Broman. Br J Ophthalmol 90:262-267, 2006). Add to this the debilitating eye diseases of age-related macular degeneration, diabetic retinopathy, and cataract, the number of people effected exceeds 100 million. This chapter focuses on ocular pharmacology with specific emphasis on basic principles and outlining where in the various ocular sites are drug targets currently in use with effective drugs but also on future drug targets.

\section{Keywords}

Ocular drugs • Ocular Pharmacology • Pharmacodynamics

\section{Introduction}

We will discuss the pharmacodynamics and the pharmacokinetic properties of ocular therapeutic agents. Pharmacokinetics is the study of drug absorption, distribution, metabolism, and excretion of drugs. Clinical pharmacokinetics applies the data gathered in these studies to design optimal dosing and minimize adverse reactions for optimal therapeutic outcomes. In general, for drugs to reach their target organs (distribution), they first need to enter into the system circulation. Drugs given orally, intramuscularly, or by transdermal patch need to be absorbed through several physiological barriers before reaching the systemic circulation. Drugs are metabolized by specific enzymes (many by the cytochrome P450 oxidases in the liver) into other metabolites that may or may not have the same pharmacological effect as the parent drug.

The eye is unique in that many of the drugs for ocular therapy, particularly those designed to lower intraocular pressure, are formulated to be absorbed through the cornea and into other tissues of the eye, including the aqueous humor. The aqueous humor is a clear fluid that flows through the anterior segment of the eye that provides nutrients and drugs to other nonvascular eye tissues. After use, many eye drugs exit the eye, enter the blood stream, and are transported to the liver where they are metabolized. The drug metabolites or the drugs themselves are then excreted from the body either through urine or feces. However, it is important to 
note that pathological conditions, genetic polymorphism, and drug-drug interaction may influence the pharmacokinetics of drugs.

Pharmacodynamics is the study of the biological effects of drugs and their mechanisms of action. Clinically, pharmacodynamics is the correlation between the dosage of a drug that is administered to a patient and the pharmacological response of the drug. It is important to note that there may not be a correlation between increases in dosages and pharmacological effects. One important reason is that the pharmacological effects of drugs are achieved through drug/receptor interactions. Drugs bind to their respective receptors, form a complex, and elicit their physiological effects. At base level, almost all receptors are available for the drugs to bind. As concentrations of drugs are increased, there are less available receptors with which to bind; therefore, the effects of the drugs may not change as drug/receptors reach saturation.

These receptor proteins can be located either on the plasma membrane, within the cytoplasm, or in the nucleus of a cell. The ability of a drug to bind to a receptor is governed by chemical/physical forces. Receptors can be classified as kinase receptors, ion channels, $\mathrm{G}$ protein-coupled receptors (those proteins coupled to $\mathrm{G}$ proteins), and intracellular receptors.

Two main terms used to describe the properties of drugs to receptors are potency and efficacy. Potency is related to dosage and efficacy is the ability of the drug to activate a receptor. As the potency of a drug decreases, the dose-response curve shifts to the right. An example is shown in Fig. 1 where drug A is more potent than drug B or C. Efficacy is a measure of the response of the drug and determined by a dose-response curve. For example, in Fig. 1, drug A and drug B have the same efficacy, but greater than drug $\mathrm{C} . \mathrm{ED}_{50}$ is the concentration of drug where there is a half-maximal effect in vivo, $\mathrm{EC}_{50}$ is the concentration of drug where there is half-

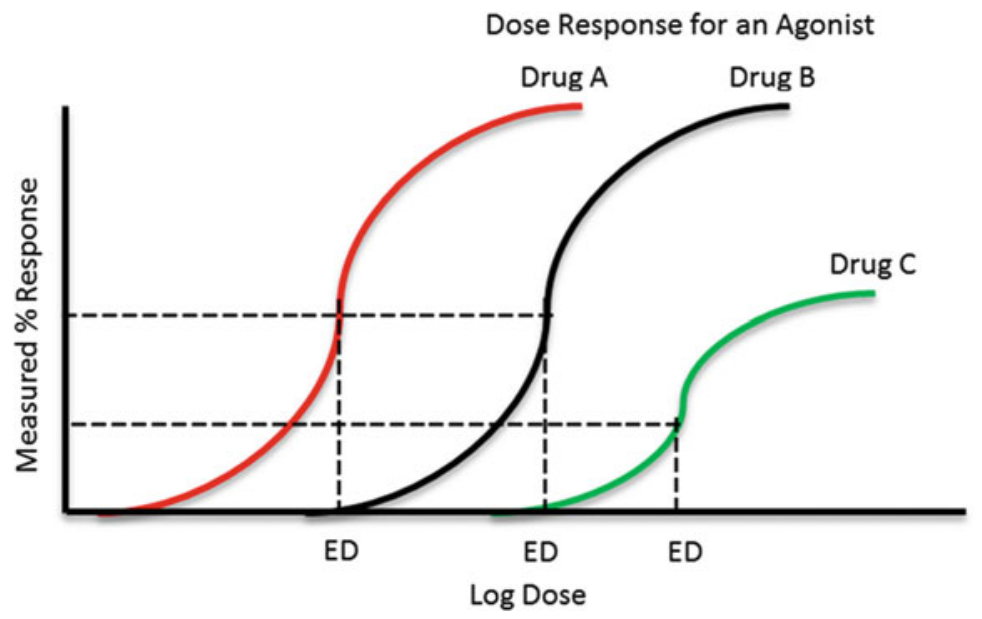

Fig. 1 Dose response curve of three different agonists visualizing drug potency and efficacy. Drug A and Drug B has the same efficacy but are more efficacious than Drug C. Drug A is more potent than Drug B and Drug C 
Fig. 2 Dose response curves of drug categorized into 4 groups by their response. Drug A is a full agonist which elicit a maximal response. A drug that does not give a full measured response is known as a partial agonist, which is depicted as Drug B. Drug C does not evoke a response and is an antagonist. Drug D produces a opposite response of Drug A and is categorized as an inverse agonist

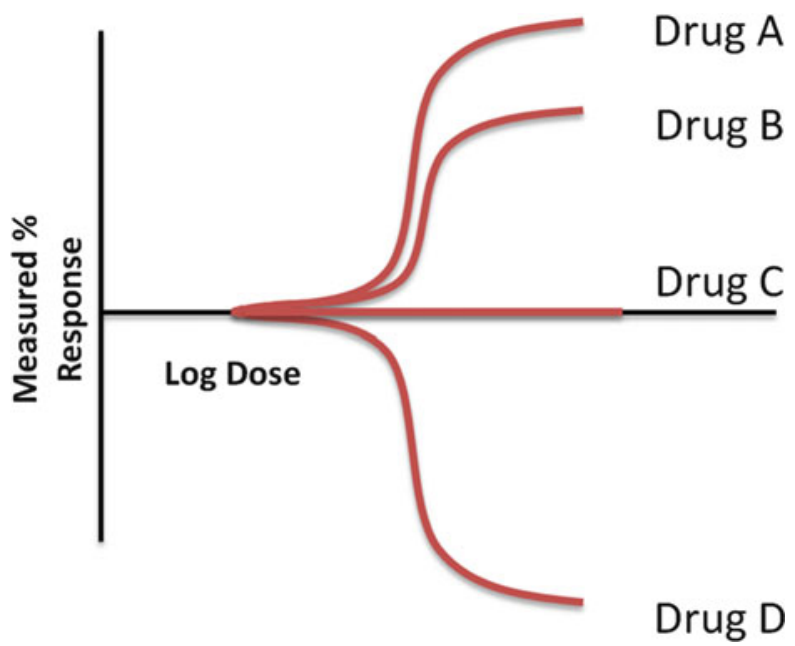

maximal effect in vitro, and $\mathrm{Kd}$ is the concentration at which half-maximal binding of drugs to receptors occurs. In addition, depending on if studies for drugs and receptors are carried out in vitro or in vivo, the curves are called concentrationresponse curves or dose-response curves, respectively.

Drugs that produce a response (or have efficacy) can be broken down into 4 major categories: full agonist, partial agonist, antagonist, and inverse agonist. A full agonist will have a maximal response (drug A on Fig. 2), where as a partial agonist will have a less than maximal response (drug B on Fig. 2). A partial agonist in the presence of a full agonist can also be considered an antagonist. An inverse agonist is a phenomenon where a drug produces an opposite effect of that produced by an agonist (drug D on Fig. 2). Antagonist have no efficacy (drug C on Fig. 2) on a receptor and act either by blocking the direct binding site of an agonist (direct antagonist) or by binding to an indirect binding site, and changing the conformation of the receptor into its inactive state so that an agonist cannot bind to the receptor (Fig. 3). A direct antagonist can be overpowered by increasing the concentration of an agonist and would cause a shift of the dose-response curve to the right; on the other hand, an indirect antagonist in the presence of an agonist cannot be overcome by increasing the concentration of the agonist.

In terms of ophthalmology, one of the best examples to compare the potency of different drug classes to a particular pharmacological effect is the intraocular pressure (IOP)-lowering agents used to treat glaucoma. These agents include the first-line agent prostaglandins, beta-blockers (timolol), selective alpha-adrenergic agonist (brimonidine), and carbonic anhydrase inhibitors, like brinzolamide. Prostaglandins are considered first line for the treatment of glaucoma because they are the most potent topical agent that can be used to lower IOP, meaning that it takes less drug to get a desired therapeutic effect. If looking at the doseresponse curves in Fig. 1, the prostaglandin agents would be drug A, while the other IOP lowering drugs would have their dose-response curves shifted to the right. 

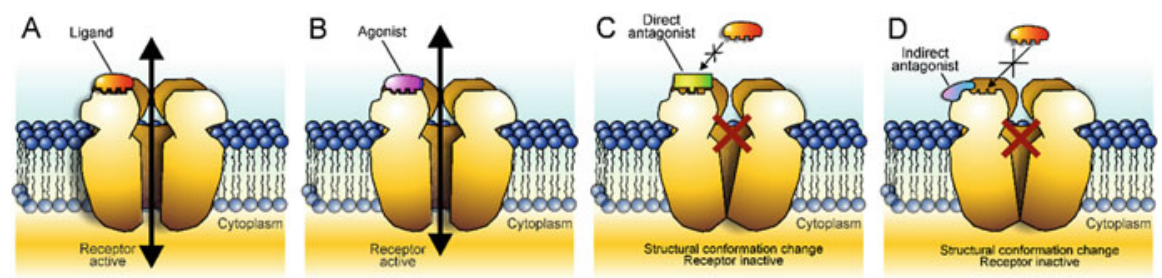

Fig. 3 Drug binding site of a receptor can cause conformational changes mediating receptor activity. When an endogenous ligand (A) or an agonist (B) binds to a receptor it produces a conformational change in the receptor opening up the receptor pore allowing the receptor to be in its active state. Ions are allowed to pass through the pore freely during the active state. A direct antagonist $(\mathrm{C})$ can have affinity to the same binding site of endogenous ligands or agonists and thus competing against these ligands and agonists and preventing receptor activation. Indirect antagonist (D), bind to receptors in regions where ligands or agonist do not bind to. However, even though a ligand or agonist can bind, the receptor is inactive due to the indirect antagonist causing conformational changes inhibiting the receptor to open its pore channel

\section{Receptor Profile}

The eye is a complex sense organ that is composed of many unique types of tissues involved in light sensing and the visual transduction cascade. Within these tissues are cells that contain various classes of proteins that can act as receptors for pharmacological drugs to interact with and produce a measurable cellular/signaling response. Of the many families of receptors, there are four major receptor protein families that are able to transduce extracellular signals to intracellular responses, thus allowing these receptor families to be major drug targets for ocular therapeutics. In this section we will present an overview of these four receptor families: ligand-gated ion channels, $\mathrm{G}$ protein-coupled receptors, kinase-linked receptors, and nuclear receptors (Fig. 4).

\subsection{Ligand-Gated Ion Channels}

Ligand-gated ion channels (LGICs) (i.e., ionotropic receptors) are receptor protein channels embedded within the plasma membrane of neuronal cells. Following the binding of a neurotransmitter, these LGICs undergo a change in conformation and allow the influx of different ions such as $\mathrm{Na}^{+}, \mathrm{K}^{+}, \mathrm{Ca}^{2+}$, or $\mathrm{Cl}^{-}$, resulting in depolarization or hyperpolarization of the neuronal cell. The fast transmission of ions following the opening of LGICs allows these channels to be involved in fast synaptic transmission between cells in the neurons of the retina (Le Novere and Changeux 2001).

There are three superfamily classes of LGICs: pentameric, tetrameric, and trimeric receptors (Lemoine et al. 2012). The pentameric LGICs are named after 


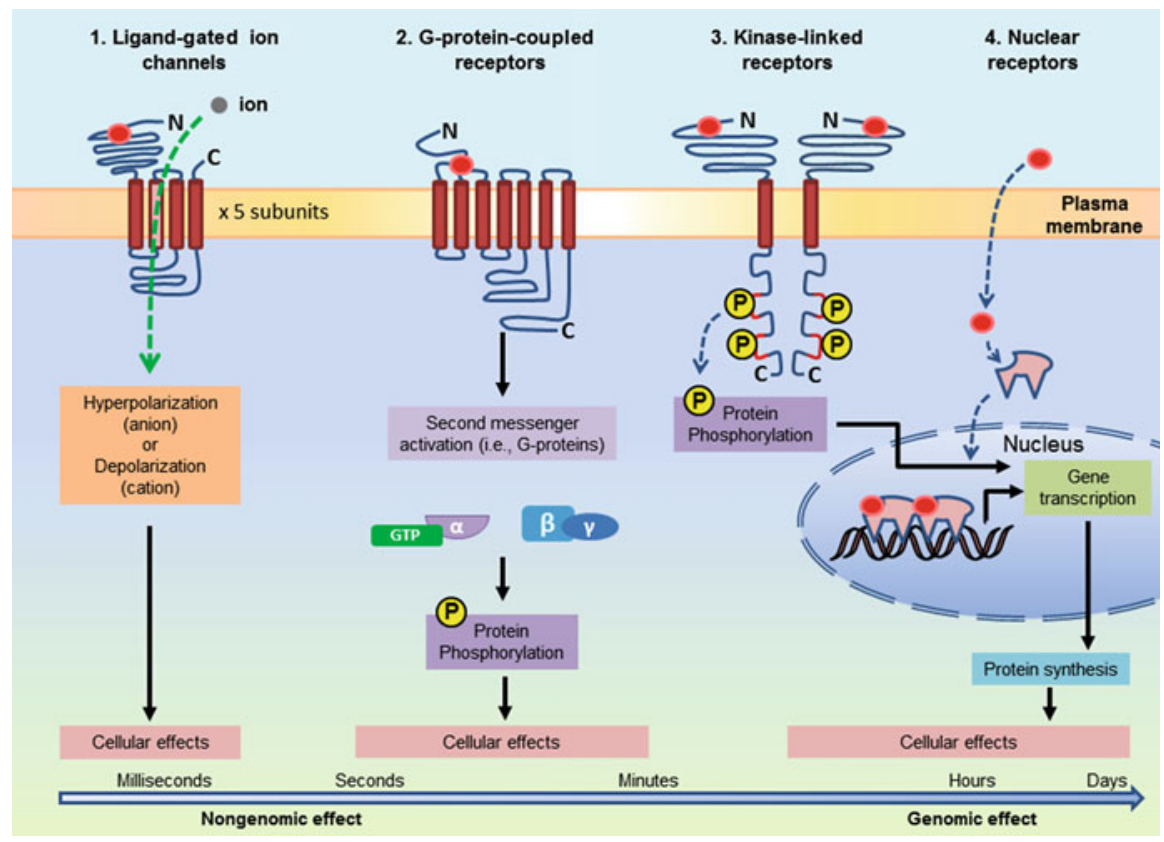

Fig. 4 A diagram of the four major receptor families, demonstrating their intracellular mechanism and the durations of their responses

five subunits that form homo- or heteromeric receptors. They are also known as Cys-loop receptors for the homologous extracellular loop that is flanked by two cysteine residues connected by a disulfide bridge. These receptors allow the movement of both cations and anions, which determines if the receptors are excitatory or inhibitory, respectively (Calimet et al. 2013). The excitatory LGICs consist of the serotonin, nicotinic acetylcholine, and zinc-activated ion channel, while the inhibitory receptors are the GABA and glycine receptors (daCosta and Baenziger 2013; Lemoine et al. 2012). The pentameric receptor's subunits have both the amino- and carboxyl-terminus on the extracellular region. These receptors include four transmembrane segments where the second membrane segment of each subunit associates with all five subunit second membranes to form a pore (Lemoine et al. 2012).

The second class of LGICs is the tetrameric receptors in which four homo or hetero subunits form the receptors. They are also known as the ionotropic glutamate receptors, which are comprised of the excitatory, nonselective cation permeable NMDA ( $N$-methyl-D-aspartate), AMPA ( $\alpha$-amino-3-hydroxy-5-methyl-4isoxazolepropionic acid), and kainate receptors (Mayer 2005). These receptor subunits contain an extracellular amino-terminal domain, an extracellular domain ligand-binding domain, a transmembrane domain (M1, M2, and M3 segment), and an intracellular carboxyl-terminal domain. Between M1 and M2 segment contains a loop that is partially reentrant to the plasma membrane, called the " $p$-loop" forming 
an ion channel when other subunits are associated (Bruening-Wright et al. 2002; Traynelis et al. 2010).

The trimeric receptors are the third class of LGIC receptors where composed of the P2X receptors which is activated by ATP (Sanderson et al. 2014). These receptors are formed by three homo or hetero subunits having two transmembrane segments (M1 and M2). Both the amino and carboxyl-terminal domains of the subunits are located in the cytosol where there is an extracellular loop, rich in cysteine residues. These receptors are mainly permeable to cations but one type is permeable to chloride anions (Lemoine et al. 2012).

Cellular signal transduction through LGICs occurs when a specific extracellular ligand binds to the N-terminus of the receptor subunits. In the case of pentameric and trimeric receptors, the ligand-binding domain is between subunits, while in tetrameric receptors, the ligand-binding domain is within the core of each subunit (Connolly and Wafford 2004; Lemoine et al. 2012). The result of the ligand binding to the receptor causes a receptor conformational change therefore opening up the channel to allow ions to flow through. The speed of the cellular signal transduction occurs within milliseconds. There are no secondary messenger biochemical systems involved with LGICs. However, the influx of $\mathrm{Ca}^{2+}$ is important where it can act as a secondary messenger, activating many calcium-binding proteins, thus further amplifying intracellular signals and producing a signal transduction cascade which could influence gene expression and changes in cell physiology (Akopian and Witkovsky 2002; Pankratov and Lalo 2014).

\subsection{G Protein-Coupled Receptors}

G protein-coupled receptors (GPCRs) modulate, dampen, or enhance intracellular signals through the coupling of intracellular secondary messengers with members of the guanosine nucleotide-binding proteins called $\mathrm{G}$ proteins. These receptors are also known as metabotropic receptors or 7-transmembrane receptors (7TM receptors), and they are the largest group of the receptor families. Over 800 receptors belong to this family where they encode roughly $4 \%$ of the human genome (Katritch et al. 2013; Kobilka 2007). The large number of GPCRs makes them the biggest target for pharmaceutical therapeutics of the eye and nearly $50 \%$ of all drugs in the market target GPCRs (Xu and Xiao 2012).

There are five classes of GPCRs: rhodopsin family (710 members), adhesion family (24 members), frizzled/taste family (24 members), secretin family (15 members), and the glutamate family (15 members) (Katritch et al. 2013). Although being diverse, GPCRs generally are similar in structure where there are three main domains: an extracellular amino-terminal domain, seven alpha-helical (hydrophobic) transmembrane protein domain, and intracellular carboxyl-terminal domain. The transmembrane protein segments are the most conserved structure between the GPCRs, whereas the amino-terminus is the least conserved (Kobilka 2007). 
Many different types of peptides/pharmacological agents can bind and act as ligands to GPCRs, ranging from photon-stimulating rhodopsin receptors in photoreceptor cells to the epinephrine-stimulating $\beta 2$-adrenergic receptors in the nonpigmented ciliary epithelium (Crider and Sharif 2002; Okada et al. 2001; Orban et al. 2014). Many small organic molecules are able to bind to within the transmembrane segments; however, larger ligands such as protein normally bind to the extracellular amino-terminus or the extracellular loops between the transmembrane segments (Kobilka 2007). Binding of a ligand to the receptor results in a conformational change; this causes the receptor to act as guanine nucleotide exchange factor. The plasma membrane resident heterotrimeric $\mathrm{G}$ proteins $(\mathrm{G} \alpha$, $\mathrm{G} \beta, \mathrm{G} \gamma$ ) are recruited then to the GPCR, promoting an exchange of a GDP for a GTP on the alpha subunit resulting in the dissociation of the G $\alpha$ subunit from the G $\beta \gamma$ subunit protein. The $\alpha$ subunit and the G $\beta \gamma$ subunit mediate other proteins as second messengers of GPCRs to transduce cellular signaling further downstream. The inherent GTPase activity of the G $\alpha$ subunit causes hydrolysis of GTP to GDP, resulting in the termination of the G protein and reuniting of the $\alpha$ subunit to the G $\beta \gamma$ subunit (Johnston and Siderovski 2007).

GPCR cellular signaling is complex and widespread which occurs in a timescale of seconds to minutes. Activation of one ligand type can induce a multitude of effector systems. GPCRs can form homo- or hetero-oligomers causing activation of multiple effector systems simultaneously (Kobilka 2007). Additionally, G proteins are very diverse in which there are 21 different $\mathrm{G} \alpha$ subunits, at least 6 different $\mathrm{G} \beta$ subunits, and $12 \mathrm{G} \gamma$ subunits (Oldham and Hamm 2008; Smrcka 2008). G $\alpha$ subunits are categorized in four major groups in which effector system they mediate (Simon et al. 1991).

1. $\mathrm{G}_{\mathrm{s}}-$ Stimulates adenylyl cyclase and open $\mathrm{Ca}^{2+}$ channels and therefore increases cAMP

2. $\mathrm{G}_{\mathrm{i}}-$ Opens $\mathrm{K}^{+}$channels and inhibits $\mathrm{Ca}^{2+}$ channels and adenylyl cyclase

3. $\mathrm{G}_{\mathrm{q}}-$ Activates phospholipase $\mathrm{C}$ and regulates the inositol phosphate system; release of internal calcium store

4. $\mathrm{G}_{12 / 13}$ - Activates Rho family GTPase signaling

The G $\beta \gamma$ subunit was believed to be a negative regulator of the $G \alpha$ subunit; however, recently the G $\beta \gamma$ subunit was discovered to regulate other proteins such as ion channels, therefore increasing the complexity of GPCR cell signaling (Smrcka 2008).

\subsection{Kinase-Linked Receptors}

Kinase-linked receptors are large transmembrane receptors, containing a large amino terminal ligand-binding domain, an $\alpha$-helical transmembrane segment, and a carboxyl catalytic domain. The effectors for these receptors range from wide variety of ligands such as growth factors, cytokines, insulin, and leptin. The binding 
of a ligand triggers receptor dimerization, followed by the autophosphorylation of the catalytic carboxyl domain. This phosphorylation of the catalytic domains induces the recruitment of other second messenger proteins to associate to the kinase-linked receptor's catalytic domain to be phosphorylated and induce an amplified signaling cascade. Activation of kinase-linked receptor elicits signaling for gene transcription to facilitate synthesize of protein required for cell growth, proliferation, differentiation, and survival of the cell in a time period of hours (Hinck 2012; Lemmon and Schlessinger 2010; Wilks 1989).

There are four main classes of kinase-linked receptors bases on their phosphorylation moiety. There are the receptor tyrosine kinases (RTKs), the serine/threonine kinases (RSTKs), the cytokine receptors, and the guanylyl cyclase (GC)-linked enzyme. RTKs contains tyrosine kinase moiety, while RSTKs are a smaller class than RTKs with a serine/threonine kinase moiety. An example of RTKs being a target for ocular pharmacology are the vascular endothelin growth factor (VEGF) receptor, where overstimulation of the receptor signals for the formation of abnormal blood vessel growth observed in wet age-related macular degeneration (AMD) or diabetic macular edema (Davuluri et al. 2009; Triantafylla et al. 2014; Witmer et al. 2002). Cytokine receptors do not have kinase enzymatic activity itself and therefore need the use of intracellular tyrosine kinases such as JAK to phosphorylate the receptor itself as well as other proteins (Patel et al. 2013). GCs are similar to RTKs and are part of the G protein-signaling cascade where they synthesize cyclic GMP from GTP (Gileadi 2014). In the disease cone dystrophy, genetic mutations in guanylate cyclase 2D result in death of cone photoreceptor cells (Garcia-Hoyos et al. 2011).

\subsection{Nuclear Receptors}

Nuclear receptors (i.e., intracellular receptors or ligand-activated transcription factors) are important drug targets for their ability to recognize many gene regulatory sequences and regulate gene expression (Aranda and Pascual 2001). These receptors are not embedded in the plasma membrane of cells but found in the cytoplasm or within the nucleus. Ligands for nuclear receptors need to be lipid soluble to allow the ligands to pass through the plasma membrane freely where it binds to the receptor. The receptor then translocates to DNA, binding to a regulatory region near the promoter called a hormone response element, acting as a transcription factor. Co-activator and corepressor factors are then recruited mediating gene transcription. The activation of nuclear receptors is important for the regulation of metabolism, development, and homeostasis (Bain et al. 2007). These receptors can regulate many genes at once, for instance, glucocorticoid receptor has over 1000 genomic binding sites regulating the transcription of numerous genes (Polman et al. 2012). The timescale for gene transcription and protein synthesis mediated by nuclear receptors occurs between hours to days (Losel et al. 2003). 
Nuclear receptors contain five regions: an amino terminal domain, a DNA-binding domain, a hinge region, a ligand-binding domain, and a carboxylterminal domain. The amino-terminal domain contains the activation function 1 (AF1) which regulates the binding and activity of the nuclear receptors to other transcription factors independently of a ligand. This region is the least conserved between different nuclear receptors. The DNA-binding domain contains a highly conserved DNA-binding domain containing two zinc fingers, which allow the receptor to recognized and bind to the hormone response element. The hinge region allows for dimerization of other nuclear receptors and transport of the nucleus. The ligand-binding domain contains activation function 2 (AF2) whose action is dependent on a bound ligand. Lastly, the carboxyl-terminal domain's function is the least understood where the domain is usually adjacent to the ligand-binding domain. (Aranda and Pascual 2001; Germain et al. 2006). Examples of nuclear receptors are glucocorticoid receptor, prostaglandin receptor (also GPCRs), retinoic acid receptor, and estrogen receptor.

\section{Drug Receptor Targets as Modulators of Ocular Function}

\subsection{Ion Channel}

An example of an ion channel as a target for therapy is the heteromultimeric epithelial sodium channel (ENaC), comprising of $\alpha \beta$ and $\gamma$ subunits that form the functional channel. ENaC is a selective cation channel that is involved in the reabsorption of sodium ions in a variety of epithelial tissues including the lumen of the gut, lung airway epithelial cells, distal nephron, and the renal collecting duct and the plasma membrane of corneal epithelial cells and the conjunctiva, as well as sodium sensor in taste bud cells. ENaC is characterized by a conductance of $5 \mathrm{pS}$ at physiological sodium concentrations and a half-saturation of ion conductance at $70 \mathrm{mM}$ sodium and is selective for sodium over potassium. ENaC is constitutively active at the plasma membrane and changes between open and closed conformations with an average open probability of $\sim 0.5$.

$\mathrm{ENaC}$ is subjected to regulation by different factors including intracellular and extracellular sodium concentrations, serine proteases, and hormonal regulation and including the activation of second messenger systems.

Hormones control the expression of active ENaC at the plasma membrane by regulating the different steps of the biosynthetic pathway such as transcription, translation, or membrane trafficking.

In the eye $\mathrm{ENaC}$ contributes to the sodium homeostasis and maintenance of tear volume and ocular surface hydration (Krueger et al. 2012), making it an interesting drug target. Currently, a compound that inhibits ENaC, P-321, is in clinical trials for the treatment of dry eye (discussed in more detail below).

GPCRs currently targeted for therapies are the histamine receptors that are activated by histamine and alpha $(\alpha)$ - and beta $(\beta)$-adrenergic receptors, also called 
adrenoceptors, that are activated by small-molecule catecholamines and prostaglandin receptors that are activated by the lipid-derived prostaglandins.

\subsection{Alpha-Adrenergic Receptors}

In the eye, studies of $\alpha$-adrenergic receptor inhibition suggest that the $\alpha_{2}$-adrenergic receptor regulates IOP (Mittag et al. 1985). Currently, there are three identified $\alpha_{2}-$ adrenergic receptor subunits expressed in ocular tissues as determined in studies in human eye using immunohistochemical, polymerase chain reaction, and dot-blot hybridization (Huang et al. 1995; Woldemussie et al. 2007). The $\alpha_{2 \mathrm{~A}}$-adrenergic receptor is localized in the anterior segment of the eye; in the nonpigmented ciliary epithelium, cornea, and conjunctival epithelia; and in the retina, including the somata of ganglion cell layer and inner nuclear layer somas. The $\alpha_{2 \mathrm{~B}}$-adrenergic receptor is located in the dendrites, axons, neurons, and glia. The $\alpha_{2 \mathrm{C}}$ immunostaining is present in pigmented ciliary epithelium, in corneal and conjunctival epithelial cells, and in the somata and inner segment of the photoreceptors.

The $\alpha$-adrenergic receptors are $\mathrm{G}$ protein-coupled receptors; activation of these receptors results in inhibition of adenylate cyclase and decreases in cAMP. Activation of $\alpha_{2 \mathrm{~A}}$-adrenergic receptors in the aqueous humor-secreting ciliary processes results in decreased aqueous humor secretion via cAMP-mediated mechanisms (Jin et al. 1994; Ogidigben et al. 1994; Wang et al. 1993) and subsequent decreases in IOP.

\subsection{Beta-Adrenergic Receptors}

The $\beta$-adrenergic receptors are divided into three subtypes based on pharmacology and molecular cloning: $\beta 1-, \beta 2-$, and $\beta 3$-adrenoceptors. Studies using fluorescent probes, autoradiography, and pharmacological tools have determined that the anterior eye segment is enriched with $\beta$-adrenergic receptors, particularly the $\beta 2$ receptors (Elena et al. 1987; Jampel et al. 1987; Lahav et al. 1978; Nathanson 1980; Neufeld et al. 1978; van Alphen 1976; Waitzman and Woods 1971). The $\beta$-adrenergic receptors have been localized to the ciliary process epithelium, isolated ciliary process epithelial cells, blood vessel walls in the ciliary processes, episclera at the limbus, the iris in the region of the sphincter muscle, the trabecular meshwork, and the ciliary muscles. In fact, sympathetic nerve fibers innervate the ciliary processes (Ehinger 1964; ten Tusscher et al. 1989) and trabecular meshwork (Sears and Sherk 1963) suggesting endogenous regulation of aqueous humor dynamics by $\beta$-adrenergic stimulation.

Sympathetic stimulation and topically applied $\beta$-adrenergic agonist, epinephrine, decrease IOP, and paradoxically, $\beta$-adrenergic antagonist, timolol (which is effective clinically in treating glaucoma), also decreases IOP. Previously, it has been suggested that differences in sites of action of $\beta$-adrenergic agonists and 
$\beta$-adrenergic antagonists might explain this complex action of adrenergic agents on IOP.

However, the regulation of and by the $\beta$-adrenergic receptors is complex. Traditionally, it is thought that binding of agonists to the receptors results in activation of adenylate cyclase, increased cAMP levels (Coca-Prados and Wax 1986), and activation of protein kinase A: activities thought to be short and transient. This may be because many GPCRs are desensitized through rapid phosphorylation by $\mathrm{G}$ protein-coupled receptor kinases within a period of less than 1 minute. These phosphorylation events may be more complex than previously thought, as phosphorylation by these kinases may result in switching of the coupling of the $\beta 2$-adrenergic receptors to different $G$ proteins to initiate different signaling outcomes (Daaka et al. 1997).

However, recent studies have demonstrated activation of $\beta$-adrenergic receptors, which resulted in elevated cAMP levels over 8 hours post agonist binding. These increases in cAMP levels are associated with extended physiological consequences. For example, activation of cardiac and neuronal $\beta$-adrenergic receptors via the sympathetic nerve fibers results in persistent contractile response in the heart during long periods of exercise and promotes long-term potentiation, necessary for learning and memory, respectively. These prolonged responses may be related to associations of the $\beta$-adrenergic receptors with scaffolding proteins, which may allow for complex interactions with the cAMP hydrolyzing enzyme, phosphodiesterase, that result in persistent $\beta$-adrenergic receptor signals (Fu et al. 2014).

\subsection{Histamine Receptors}

Histamine is a monoamine molecule synthesized from the amino acid L-histidine by histidine decarboxylase in certain cells, such as mast cells, basophils, enterochromaffin-like cells, and neurons. Histamine is ubiquitous and mediates inflammatory reactions via binding to histamine receptors. Currently, there are four identified histamine receptor subtypes: $\mathrm{H}_{1}, \mathrm{H}_{2}, \mathrm{H}_{3}$, and $\mathrm{H}_{4}$ receptors.

$H_{1}$ receptors are $G_{\alpha q}$ protein-coupled receptors that are expressed in many tissues in the body, including the eye, gastrointestinal tract, central nervous system, lungs, vascular smooth muscle cells, and endothelial cells. $\mathrm{H}_{2}$ receptors are $\mathrm{G}_{\alpha \mathrm{s}}$ protein-coupled receptors expressed in the gastrointestinal tract, the central nervous system, smooth muscles, and endothelial cells. $\mathrm{H}_{3}$ and $\mathrm{H}_{4}$ receptors are $\mathrm{G}_{\alpha i}$ proteincoupled receptors that are highly expressed in the central nervous system and blood cells, respectively. Of the four receptors, $\mathrm{H}_{1}$ and $\mathrm{H}_{2}$ are important drug targets with clinical therapeutic agents designed to block the effects mediated by these receptors; $\mathrm{H}_{1}$ receptor blockers (ketotifen $\left(\mathrm{p} K_{\mathrm{i}} 8.6\right)$, chlorpheniramine $\left(\mathrm{p} K_{\mathrm{i}} 8.15\right)$, fexofenadine $\left(\mathrm{p} K_{\mathrm{i}} 7.57\right)$, and desloratadine $\left(\mathrm{p} K_{\mathrm{i}}\right.$ 9.01)) are used as antihistamines to treat allergic reactions mediated by histamine, and $\mathrm{H}_{2}$ receptor blockers (ranitidine and cimetidine) to treat gastric ulcers.

The $\mathrm{H}_{1}$ receptors play a wide role in the pathological processes of allergy, including anaphylaxis, asthma, allergic rhinitis, atopic dermatitis, and 
conjunctivitis. In addition to inflammatory allergenic effects of activation of $\mathrm{H}_{1}$ receptors, it also triggers maturation of dendritic cells and modulates type 1 and type $2 \mathrm{~T}$ helper cells. Immunostaining, Western blots, and RT-PCR demonstrate $\mathrm{H}_{1}$, $\mathrm{H}_{2}$, and $\mathrm{H}_{4}$ subtypes in mucosal biopsies from the human conjunctiva (Leonardi et al. 2011) and $H_{1}$ receptors in corneal endothelial cells (Srinivas et al. 2006). Pharmacological studies (Kirkegaard et al. 1982; Umemoto et al. 1987; Woodward et al. 1986), $H_{1}$ receptor knockout animals (Izushi et al. 2002), and RT-PCR (Leonardi et al. 2011) confirmed the involvement of the $\mathrm{H}_{1}$ receptor in allergic inflammation associated with conjunctivitis.

Allergic conjunctivitis occurs when allergens enter the conjunctival stroma and bind to $\operatorname{IgE}$ on mast cells or basophils. The cross-linking of allergens and $\operatorname{IgE}$ on mass cells induces release of histamine from the mast cells and release of other allergic mediators including cytokines. In response to histamine release, blood vessels dilate and become permeable. Histamine binding to its receptors in the conjunctiva results in clinical manifestations of itching, swelling, and redness, which allow for several targets for drug intervention: mast cell stabilization, inhibition of histamine release, or inhibition of histamine receptors. Antagonism of the $\mathrm{H}_{1}$ receptor is a targeted therapeutic approach for the treatment of these conditions.

\subsection{Prostaglandin Receptors}

The role of prostaglandins in regulating IOP was studied several years prior to identifying prostaglandin receptors in the eye. The effects of prostaglandin are biphasic: an initial short-term increase in IOP followed by a sustained decrease in IOP (Camras et al. 1977; Starr 1971).

The synthesis of prostaglandins from arachidonic acid is catalyzed by the enzymes cyclooxygenase (COX) and prostaglandin synthase. Prostaglandins are ubiquitous, and the types produced in a given cell are dependent on the expression profile of the prostaglandin synthetic enzymes in that particular cell. Prostaglandins are autocrine or juxtacrine modulators that have diverse pharmacological effects on the central nervous system and the cardiovascular, gastrointestinal, and visual systems. Additionally, prostaglandins have been associated with diseases such as cancer, inflammation, cardiovascular diseases, and hypertension. The use of nonsteroidal anti-inflammatory drugs (NSAIDs) as inhibitors of cyclooxygenase in the clinical treatment of inflammatory diseases and the use of prostaglandin analogs in the treatment of glaucoma underscore the physiological importance of prostaglandins.

The biologically active prostaglandins (PG) are $\mathrm{PGE}_{2}, \mathrm{PGF}_{2 \alpha}, \mathrm{PGD}_{2}, \mathrm{PGL}_{2}$ (prostacyclin), and $\mathrm{TXA}_{2}$ (thromboxane) that interact with prostaglandin receptors EPs (1-4), FP, DP, IP, and TP, respectively. Quantitative autoradiography, in situ hybridization, immunohistochemistry, and RT-PCR confirmed EP and FP receptors in the ciliary epithelium, cornea, conjunctiva, iris sphincter muscle, longitudinal ciliary muscle, retinal ganglion cells, trabecular meshwork, sclera, Muller cells, and 
optic nerves (Anthony et al. 2001; Davis and Sharif 1999; Matsuo and Cynader 1992; Ocklind et al. 1996; Schlotzer-Schrehardt et al. 2002), with differential distribution. The uveoscleral pathway through which aqueous humor exits the eye consists of the iris, ciliary muscles, supraciliary and suprachoroidal spaces, and the sclera, suggesting physiological regulation by endogenous prostaglandins. Clinically relevant targeting to the FP receptors result in IOP lowering.

$\mathrm{FP}$ receptors are $\mathrm{Gq}$ protein-coupled receptors; $\mathrm{PGF}_{2 \alpha}$ binding results in increased IP3/DAG and phosphorylation of myosin light-chain kinase (MLCK). In fact, the effects of latanoprost, a $\mathrm{PGF}_{2 \alpha}$ analog, are mediated via IP3. Studies have demonstrated that activation of the $\mathrm{PGF}_{2 \alpha} / \mathrm{FP} / \mathrm{IP} 3 / \mathrm{MLCK}$ system may result in contraction-relaxation of the iris sphincter muscle in the anterior segment of the eye that influences aqueous humor outflow and IOP lowering (Ansari et al. 2003).

\subsection{Kinase-Linked Receptors}

An example of a kinase-linked receptor that is clinically relevant as a therapeutic target is the vascular endothelial growth factor (VEGF) family of protein tyrosine kinase receptors; anti-VEGF therapy is currently used for the treatment of age-related macular degeneration. While there are five identified members of the VEGF family, VEGF-A, VEGF-B, VEGF-C, VEGF-D, and placental growth factor (PlGF), alternative splicing of corresponding mRNAs results in many isoforms of VEGF-A, VEGF-B, and PlGF. VEGF receptors include three protein tyrosine kinases, VEGFR-1, VEGFR-2, and VEGFR-3, and two nonenzymatic receptors, neuropilin-1 and neuropilin-2, localized to vascular endothelial cells. These specialized localization and distribution of VEGFRs allow for the selectivity and specificity of VEGF's actions. VEGFR-1 binds to VEGF-A, VEGF-B, and PIGF with high affinity, while VEGFR-2 binds with lower affinity to some isoforms of VEGF-A and higher affinity to VEGF-C and VEGF-D; however, binding results in different biological effects. VEGF plays a fundamental role in the process of neovascularization in normal physiological processes as VEGFR-1, VEGFR-2, and VEGFR-3 null mice failed to form organized blood vessels which resulted in death between embryonic days 7-9 (Dumont et al. 1998; Fong et al. 1995; Hiratsuka et al. 1998; Shalaby et al. 1995).

Studies in normal monkey eyes using RT-PCR and immunohistochemistry detected constitutively expressed mRNA and proteins of VEGF-A, respectively, particularly the VEGF121 and VEGF165 isoforms, in the conjunctiva, iris, retina, and choroid-retinal pigment epithelial layers. Within the retina, VEGF was expressed in the ganglion, inner nuclear layer (Stone et al. 1995), retinal pigment epithelial layer, and cone photoreceptors (Kim et al. 1999). VEGF receptors, VEGFR-1 and VEGFR-2 mRNA, were detected in the iris, the retina, and the choroid-retinal pigment epithelial layers (Kim et al. 1999; Wen et al. 1998).

There are alterations in the VEGF system in pathological states. Immunohistological studies in humans demonstrated increased VEGF expression in the retinal pigment epithelium and the outer nuclear layer in the maculae of 
patients with age-related macular degeneration (Kliffen et al. 1997). Studies that demonstrated sustained release of VEGF resulted in retinal neovascularization and breakdown of the blood-retina barrier in rabbits and primates (Ozaki et al. 1997). Retinal branch vein occlusion in cats and primates resulted in increases of VEGF and activation of protein tyrosine phosphorylation and the tyrosine kinase pathway proteins, phospholipase C gamma and MAPK (Hayashi et al. 1997; Miller et al. 1994; Pierce et al. 1995).

\section{$4 \quad$ Drug Interaction and Ocular Therapy}

Of the many eye diseases and disorders, glaucoma, AMD, uveitis, and some corneal disorders are treated with medication. We will discuss the types of drug and receptor targets.

\subsection{Cornea}

The cornea is a clear, avascular structure that covers the front of the eye and serves as a protective agent and focuses the light to the retina. There are as many identified disorders and diseases that affect the cornea. Of these, we will briefly discuss the conditions that utilize drugs as therapeutic strategies.

\subsubsection{Dry Eye}

In individuals with dry eye, there is an imbalance in tear production, drainage, and absorption. This results in the eyes' inability to produce enough or good quality tears needed to keep the surface of the eye lubricated, help in wound healing, and protect against infection.

Currently, this condition is treated with artificial tears (lubricating drops) or compounds that allow the eye to produce tears, for example, cyclosporine (Kaswan et al. 1989; Yoshida et al. 1999), which is an immunomodulator. A cyclosporine ophthalmic emulsion (Restasis, www.restasis.com), the only FDA-approved drug to treat dry eye, works by causing the eye to produce tears. While the mechanism (s) of action is unknown, inhibition of calcineurin (a serene/threonine protein phosphatase) and subsequent modulation of T-cell activity may play a role (Gilger et al. 2013; Kapoor et al. 2010).

A novel ophthalmic solution called P-321 Ophthalmic Solution is in an FDA-approved phase 1 clinical trial (ClinicalTrials.Gov). P-321 is a potent epithelial sodium channel (ENaC) blocker (www.parion.com). Inhibition of $\mathrm{ENaC}$ prevents the absorption of tears by the cornea and conjunctiva which results in increased tear volume on the ocular surface (Hara et al. 2010).

P-321 was devised to be held on the cornea, with limited systemic distribution. The pharmacokinetic studies for P-321 demonstrate an $\mathrm{IC}_{50}$ of $1.9 \pm 0.75 \mathrm{nM}$ in human epithelial cells and a metabolic stability of P-321 in body blood products; which the drug is rapidly cleared from plasma. The effects of P-321/ENaC 
modulation of tear volume are achieved within 30 min of drug administration and are maintained for at least $6 \mathrm{~h}$.

\subsubsection{Allergies}

Allergies that cause the eye to itch and produce excess tears and burn are common in individuals particularly in warm, dry climates with high pollen count. Because histamines are mediators in allergic reactions, itching due to allergies is usually treated with antihistamines or histamine antagonists. Thus, blocking the actions of histamines prevents the itching associated with the allergic reactions.

In the eye, histamine binds to the histamine-1 (H1) receptor, a member of the GPCR family of receptors, and achieves its effects via activation of $\mathrm{Gq}$ and inositol phosphate increases and/or calcium mobilization.

Ketotifen fumarate ophthalmic solution (Zaditor drops; www.zaditor.com) is a noncompetitive histamine-1 (H1) receptor antagonist. Antihistamines block the release of histamine from the histamine-producing mast cells (Okayama et al. 1994) as well as block the binding of histamine to its receptors. Zaditor works by blocking both the $\mathrm{H} 1$ receptor and the release of histamine from mast cells.

Ketotifen fumarate pharmacokinetic profile was not obtained for topical use, but was obtained for intravenous, intranasal, oral, and rectal administrations. Bioavailability after oral administration was the lowest among the four routes, possibly due to the first-pass metabolism by the liver. No systemic effects were observed with topical application of the drug.

\subsubsection{Conjunctivitis}

Conjunctivitis or pink eye may occur because of bacteria or allergen. Bacterial conjunctivitis is treated with antibiotics (Azari and Barney 2013; Sheikh and Hurwitz 2001) such as azithromycin eye drops (www.azasite.com) (Cochereau et al. 2007), gatifloxacin ophthalmic solution (www.allergan.com), and levofloxacin. Allergic conjunctivitis is treated with bepotastine besilate ophthalmic solution (Bepreve, www.bausch.com) which is a selective $\mathrm{H} 1$ receptor antagonist (McCabe and McCabe 2012) and, like ketotifen fumarate, inhibits the release of histamine from mast cell.

\subsubsection{Bacterial Infections}

Bacterial keratitis is a common bacterial infection of the cornea caused by Staphylococcus aureus and Pseudomonas aeruginosa (O'Brien 2003; Willcox 2011) which cause microbial contamination of contact lens. Activation of Toll-like receptors on corneal epithelial cells by Pseudomonas aeruginosa (Zhang et al. 2003) results in production of inflammatory mediators such as cytokines and chemokines (Sadikot et al. 2005). Aminoglycoside antibiotic solution such as gentamicin sulfate ophthalmic (www.bausch.com) is also used. 


\subsubsection{Viral Infections}

Viral infections such as herpes zoster (shingles) which is caused by the varicellazoster virus or ocular herpes caused by herpes simplex virus are treated with antiviral eye drops (Castela et al. 1994). Antiviral agents include both topical and oral medications. Examples of topical medications are idoxuridine ophthalmic (no longer used in the United States), ganciclovir ophthalmic gel (Colin 2007) (Zirgan, www.bausch.com), and trifluridine (Viroptic ophthalmic solutions). Ganciclovir is a DNA polymerase inhibitor and prevents viral replication by protein phosphorylation events (Littler et al. 1992). The mechanisms of action of trifluridine are not completely understood; however, it interferes with viral replication by blocking DNA transcription (Carmine et al. 1982; Suzuki et al. 2011).

\subsection{Uvea}

\subsubsection{Uveitis}

The uvea comprises the ciliary processes, choroid, and iris, and inflammation of these tissues is called uveitis. Uveitis can be secondary to other diseases including AIDs, tuberculosis, and sarcoidosis. The target tissues are the ciliary processes, choroid, and iris. To reduce the inflammation, corticosteroids, which may be antiinflammatory or immunosuppressive agents, are used. Examples of steroid antiinflammatory include prednisone and fluocinolone (Callanan et al. 2008; The Multicenter Uveitis Steroid Treatment Trial Research et al. 2011), and immunosuppressive agents include methotrexate, mycophenolate, azathioprine, and cyclosporine. In some cases, immune-specific biological response modifiers such as rituximab, abatacept, daclizumab, and the TNF- $\alpha$ inhibitors, infliximab and adalimumab, are also used (Larson et al. 2011; Nussenblatt et al. 1999; Smith et al. 2001). Prednisone, a mixture of glucocorticoid and mineralocorticoid, would likely bind to both intracellular glucocorticoid (GR) and mineralocorticoid receptor (MR) complexes and control gene transcription via direct and indirect mechanisms.

\subsection{Retina/Anterior Eye Segment}

\subsubsection{Age-Related Macular Degeneration (AMD)}

AMD is a leading cause of irreversible vision loss worldwide. AMD involves losses of cone photoreceptor cells in the macular region of the retina and results in blurred vision and eventually loss of central vision. Two types of AMD have been characterized, non-neovascular AMD (dry) and neovascular AMD (wet AMD). Aberrant VEGF expression has been associated with the pathophysiology of neovascular AMD (Kvanta et al. 1996) and results in abnormal growth of new blood vessels with structural defects that may lead to seepage of vascular contents and bleeding, thus leading to damages to the delicate macula. Of the two types of AMD, drug treatment options for neovascular AMD involve antivascular 
endothelial growth factor (VEGF) therapy. This therapy is aimed at reducing the amounts of VEGF that is secreted in the eye, particularly the choroid layer of the eye.

The target tissues for anti-VEGF therapy are vascular endothelial cells. Examples of existing therapies include monoclonal antibody to VEGF (Krzystolik et al. 2002), such as bevacizumab (Avastin) and ranibizumab (Lucentis) (Avery et al. 2006; Rosenfeld et al. 2005, 2006); aptamers (small oligonucleotides that bind to VEGF), such as pegaptanib (Chakravarthy et al. 2006) (Macugen) that binds to and inhibits extracellular VEGF; and VEGF receptor proteins 1 and 2 that are fused to the Fc portion of IgG (Nguyen et al. 2006); this acts as a competitive receptor for endogenous VEGF and an example is aflibercept (Heier et al. 2012) (Eylea). Binding of these agents to VEGF decreases functional VEGF in the vascular tissues and halts the choroidal neovascularization and leakage from these immature blood vessels that cause damage to the retinal layers.

\subsubsection{Glaucoma}

While glaucoma is characterized as an optic neuropathy, current treatments available are aimed at decreasing IOP that is produced in the anterior segment of the eye. Maintenance of proper IOP depends on a unique balance between aqueous humor secretion by the ciliary processes and outflow through the trabecular meshwork and Schlemm's canal (pressure-dependent pathway) and the uveoscleral pathway (pressure-independent pathway). While some drugs have shown neuroprotective properties, no neuroprotective agent has gone past stage III clinical trials for the treatment of glaucoma. Studies involving human subjects (reviewed in van der Valk et al., 2009) demonstrated the efficacies of alpha-adrenergic agonists (alpha $(\alpha)$ agonist), beta-adrenergic antagonist (beta-blockers), carbonic anhydrase inhibitors, cholinergics (miotic), prostaglandin analogs, and combination therapies which are currently used in the treatment of ocular hypertension and glaucoma. Other IOP regulators and neuroprotective agents include the cannabinoids, Latrunculin A and $\mathrm{B}$, rho kinase (ROCK) inhibitors, adenosine, nitric oxide, sigma-1 receptor agonists, and endothelin antagonists.

Examples of alpha $(\alpha)$-adrenergic agonists are apraclonidine (Iopidine) which is only marketed in some countries and brimonidine tartrate (Alphagan P) and clonidine. Target tissues include the ciliary processes, the uveoscleral outflow pathway, and the retina (Toris et al. 1995; Wheeler et al. 2001). Activation of $\alpha_{2 \mathrm{~A}}$-adrenergic receptors in ciliary processes decreases aqueous humor secretion (Jin et al. 1994; Ogidigben et al. 1994; Wang et al. 1993). Although $\alpha$-adrenergic receptors are localized in TM, studies fail to show regulation of conventional outflow facility. The retina contains the $\alpha_{2 \mathrm{~A}}$-adrenergic receptors (Wheeler et al. 2001), and brimonidine has been shown to be neuroprotective in glaucoma animal models (WoldeMussie et al. 2001) possibly by modulation of brain-derived neurotrophic factor (BDNF) (Gao et al. 2002).

Examples of beta $(\beta)$-adrenergic antagonists $(\beta$-blockers) are betaxolol $\mathrm{HCl}$ (a selective $\beta_{1}$ antagonist) and timolol (nonselective $\beta_{1}$ - and $\beta_{2}$-adrenergic receptor antagonists), carteolol, metipranolol, and levobetaxolol. Target tissues are the 
ciliary processes (Potter and Rowland 1978) which contain $\beta_{1^{-}}$and $\beta_{2}$-adrenergic receptors and the retina (Elena et al. 1987; Ferrari-Dileo 1988). Activation of $\beta$-adrenergic antagonist decreases IOP by decreasing aqueous humor secretion in ciliary processes and decreasing the flow of aqueous humor. Both betaxolol $\mathrm{HCl}$ and timolol are neuroprotective in glaucoma animal models. While $\beta$-adrenergic antagonist is also involved in blood flow to the optic nerve head, it is not clear if its regulation of vascular tone is protective. Timolol, nonselective $\beta_{1}$ - and $\beta_{2}$-adrenergic receptor antagonists, protects RGCs in rat glaucoma model. The signaling pathways by which $\beta$-blockers achieve their effects involve inhibition of adenylate cyclase and decreased cAMP in ciliary processes (Crider and Sharif 2002). In the retina inhibition of $\beta$-adrenergic receptors may involve regulation of calcium and sodium channels, NMDA receptors, and BDNF regulation.

Carbonic anhydrase inhibitors are brinzolamide (Azopt) and dorzolamide (Trusopt) and are used as eye drops. Methazolamide (Neptazane) and acetazolamide (Diamox) are used as oral medications (pills). Carbonic anhydrase inhibitors target the ciliary processes (Maren and Conroy 1993; Wistrand 1959) where they inhibit the enzyme carbonic anhydrase II, a major regulator of aqueous humor secretion.

The cholinergics (miotic), including pilocarpine and carbachol, target the ciliary muscles in the ciliary body. IOP is decreased by constriction of the ciliary muscles by the cholinergics. Ciliary muscle constrictions result in regulation of the trabecular meshwork and Schlemm's canal to increase outflow of aqueous humor.

Synthetic prostaglandin analogs include travoprost (Travatan), bimatoprost (Lumigan), tafluprost (Zioptan), and latanoprost (Xalatan) (reviewed in Toris et al., 2008). Like latanoprost, the others are PGF2 $\alpha$ analogs and bind with high affinity to the FP receptor. Prostaglandins target the uveoscleral outflow pathway primarily to allow for increased pressure-independent outflow of aqueous humor. In some cases the trabecular meshwork and Schlemm's canal are regulated by prostaglandins. In experimental animal models, latanoprost has been shown to protect RGCs from death by antagonizing glutamate toxicity and inhibiting caspase 3 (Kanamori et al. 2009).

Combined therapies include brimonidine tartrate and timolol maleate, $\alpha$ agonist, and $\beta$-blocker; dorzolamide HCI and timolol maleate, carbonic anhydrase inhibitor, and $\beta$-blocker; and brinzolamide/brimonidine tartrate, carbonic anhydrase inhibitor, and $\alpha$ agonist.

\subsection{Other Regulators of IOP}

Cannabinoid CB1 receptors are localized in the trabecular meshwork and ciliary processes, while CB1 and CB2 mRNA are expressed in the retina. The cannabinoid receptors are $\mathrm{G}$ protein-coupled receptors and cannabinoids binding to its receptor decrease IOP by increasing aqueous humor outflow facility. In $\beta$-adrenergic knockout mice and $\mathrm{CB}(1)(-/-)$ mice, $\mathrm{CB}$ receptor agonist could not decrease IOP suggesting that $\mathrm{CB} 1$ receptor involvement in IOP regulation may be mediated by 
$\beta$-adrenergics. In a rat model of glaucoma, cannabinoids have been shown to be protective.

Latrunculins A and B decrease IOP by increasing aqueous humor outflow facility by disrupting actin filaments in the trabecular meshwork and altering the cell's stiffness. Many of latrunculin's effects also involve the regulation of extracellular matrix proteins.

Rho kinase (ROCK) inhibitors target several tissues involved in IOP regulation and proper maintenance of vision, including the trabecular meshwork, the ciliary muscle, RGCs, and optic nerve head. ROCK decreases IOP by increasing aqueous humor outflow facility. In experimental animals, ROCK is also neuroprotective.

Adenosine receptors are expressed in the ciliary processes, trabecular meshwork, retina including Muller cells and RGCs, and the optic nerve head. Activation of adenosine receptors has been shown to lower IOP and, in experimental glaucoma, is involved in neuroprotection.

Studies have confirmed the involvement of renin-angiotensin system (RAS) in regulating IOP (reviewed in Vaajanen and Vapaatalo, 2011). Captopril, an angiotensin-converting enzyme (ACE) inhibitor used for the treatment of systemic hypertension, reduced IOP in normal and glaucomatous individuals. Additionally, other hypertension-reducing agents, enalapril, ramipril, and fosinopril, reduced IOP in glaucoma animal models. More recent studies suggest that activation of the endogenous angiotensin-converting enzyme 2 (ACE2) and the Mas receptor decreased IOP in experimental model of glaucoma without changing systemic blood pressure (Foureaux et al. 2013).

Nitric oxide synthase, the synthetic enzyme of nitric oxide (NO), is expressed in the ciliary processes, trabecular meshwork, Schlemm's canal, retina, and optic nerve head. NO regulation of IOP is multifactorial. It decreases IOP by decreasing aqueous humor secretion, increasing aqueous humor outflow, and regulating vascular tone. NO could be neuroprotective or degenerative, depending on the concentrations in the tissue. In ciliary processes cholinergic stimulation regulates nitric oxide synthase activity (Ellis et al. 2001). In Schlemm's canal, shear stress causes increases in NO (Ashpole et al. 2014) which binds to soluble guanylate cyclase and activates the enzyme. In trabecular meshwork and Schlemm's canal, activation of soluble guanylate cyclase results in increased cGMP levels and activation of protein kinase G. The high conductance calcium-activated potassium channel is regulated by protein kinase $\mathrm{G}$, and this regulation results in changes in cell volume and or cell contractility (Dismuke et al. 2008).

The sigma-1 receptor $(\sigma-1 \mathrm{r})$ is a $26 \mathrm{kD}$ transmembrane, non-opioid receptor that has been localized to the ciliary processes, retina, RGCs, and Muller cells. The $\sigma-1 \mathrm{r}$ has been shown to be neuroprotective in RGCs both in vivo and in vitro (Mueller et al. 2014; Smith et al. 2008), by inhibiting overexpression of the apoptotic protein, Bax, and TNF-related apoptosis inducing ligand (TRAIL) and phosphorylation of JNK (Cantarella et al. 2007). The $\sigma$-1r regulation of IOP is dependent on the species; activation of the $\sigma-1 \mathrm{r}$ results in decrease IOP in rabbits, although in $\sigma-1 \mathrm{r}$ knockout mice there were no changes in IOP when compared to wild-type mice. The $\sigma-1 \mathrm{r}$ is found on the endoplasmic reticulum (ER) and has the ability to form 
complexes with the mitochondrion-associated ER membrane and/or translocate to interact with ionotropic channels located at the plasma membrane and appear to be involved in regulating the cells' ion channels (Mueller et al. 2013). In fact, many of the actions of $\sigma-1 \mathrm{r}$ involve inhibition of voltage-gated channels or potentiation of ligand-gated channels.

Endothelin-1 is expressed in the iris, ciliary body, and retina. In pathological conditions there are increased levels of endothelin which are detrimental to the health of the tissue (Tezel et al. 1997). Endothelin receptors $\mathrm{ET}_{\mathrm{A}}$ and $\mathrm{ET}_{\mathrm{B}}$ are $\mathrm{G}$ protein-coupled receptors including $\mathrm{G}_{\alpha \mathrm{s}}, \mathrm{G}_{\alpha \mathrm{i}}$, and $\mathrm{G}_{\alpha \mathrm{\alpha q}}$ suggesting many different signaling pathways and multiple biological actions, whose actions are mediated by phospholipase $\mathrm{C} /$ inositol triphosphate and intracellular calcium. Above-normal endothelin levels result in an imbalance in the system resulting in sustained calcium influx, membrane depolarization, and eventual cell death. Inhibition of this system results in restoration of the tissues health (reviewed in Krishnamoorthy et al., 2008, and Prasanna et al., 2011).

\section{References}

Akopian A, Witkovsky P (2002) Calcium and retinal function. Mol Neurobiol 25(2):113-132

Ansari HR, Davis AM, Kaddour-Djebbar I, Abdel-Latif AA (2003) Effects of prostaglandin F2alpha and latanoprost on phosphoinositide turnover, myosin light chain phosphorylation and contraction in cat iris sphincter. J Ocul Pharmacol Ther 19(3):217-231

Anthony TL, Lindsey JD, Aihara M, Weinreb RN (2001) Detection of prostaglandin EP(1), EP(2), and FP receptor subtypes in human sclera. Invest Ophthalmol Vis Sci 42(13):3182-3186

Aranda A, Pascual A (2001) Nuclear hormone receptors and gene expression. Physiol Rev 81 (3):1269-1304

Ashpole NE, Overby DR, Ethier CR, Stamer WD (2014) Shear stress-triggered nitric oxide release from Schlemm's canal cells. Invest Ophthalmol Vis Sci 55(12):8067-8076

Avery RL, Pieramici DJ, Rabena MD, Castellarin AA, Nasir MA, Giust MJ (2006) Intravitreal bevacizumab (Avastin) for neovascular age-related macular degeneration. Ophthalmology 113 (3):363-372.e365.

Azari AA, Barney NP (2013) Conjunctivitis: a systematic review of diagnosis and treatment. JAMA 310(16):1721-1730

Bain DL, Heneghan AF, Connaghan-Jones KD, Miura MT (2007) Nuclear receptor structure: implications for function. Annu Rev Physiol 69:201-220

Bruening-Wright A, Schumacher MA, Adelman JP, Maylie J (2002) Localization of the activation gate for small conductance Ca2+-activated K+ channels. J Neurosci 22(15):6499-6506

Calimet N, Simoes M, Changeux JP, Karplus M, Taly A, Cecchini M (2013) A gating mechanism of pentameric ligand-gated ion channels. Proc Natl Acad Sci U S A 110(42):E3987-E3996

Callanan DG, Jaffe GJ, Martin DF, Pearson PA, Comstock TL (2008) Treatment of posterior uveitis with a fluocinolone acetonide implant: three-year clinical trial results. Arch Ophthalmol 126(9):1191-1201

Camras CB, Bito LZ, Eakins KE (1977) Reduction of intraocular pressure by prostaglandins applied topically to the eyes of conscious rabbits. Invest Ophthalmol Vis Sci 16 (12):1125-1134 
Cantarella G, Bucolo C, Di Benedetto G, Pezzino S, Lempereur L, Calvagna R, Clementi S, Pavone P, Fiore L, Bernardini R (2007) Protective effects of the sigma agonist Pre-084 in the rat retina. Br J Ophthalmol 91(10):1382-1384

Carmine AA, Brogden RN, Heel RC, Speight TM, Avery GS (1982) Trifluridine: a review of its antiviral activity and therapeutic use in the topical treatment of viral eye infections. Drugs 23 (5):329-353

Castela N, Vermerie N, Chast F, Sauvageon-Martre H, Denis J, Godard V, Goldschmidt P, Pouliquen Y (1994) Ganciclovir ophthalmic gel in herpes simplex virus rabbit keratitis: intraocular penetration and efficacy. J Ocul Pharmacol 10(2):439-451

Chakravarthy U, Adamis AP, Cunningham ET Jr, Goldbaum M, Guyer DR, Katz B, Patel M (2006) Year 2 efficacy results of 2 randomized controlled clinical trials of pegaptanib for neovascular age-related macular degeneration. Ophthalmology 113(9):1508 e1501-e1525

Coca-Prados M, Wax MB (1986) Transformation of human ciliary epithelial cells by simian virus 40: induction of cell proliferation and retention of beta 2-adrenergic receptors. Proc Natl Acad Sci U S A 83(22):8754-8758

Cochereau I, Meddeb-Ouertani A, Khairallah M, Amraoui A, Zaghloul K, Pop M, Delval L, Pouliquen P, Tandon R, Garg P et al (2007) 3-day treatment with azithromycin 1.5\% eye drops versus 7 -day treatment with tobramycin $0.3 \%$ for purulent bacterial conjunctivitis: multicentre, randomised and controlled trial in adults and children. Br J Ophthalmol 91(4):465-469

Colin J (2007) Ganciclovir ophthalmic gel, 0.15\%: a valuable tool for treating ocular herpes. Clin Ophthalmol (Auckland, NZ) 1(4):441-453

Connolly CN, Wafford KA (2004) The Cys-loop superfamily of ligand-gated ion channels: the impact of receptor structure on function. Biochem Soc Trans 32(Pt3):529-534

Crider JY, Sharif NA (2002) Adenylyl cyclase activity mediated by beta-adrenoceptors in immortalized human trabecular meshwork and non-pigmented ciliary epithelial cells. J Ocular Pharmacol Therapeut 18(3):221-230

Daaka Y, Luttrell LM, Lefkowitz RJ (1997) Switching of the coupling of the [beta]2-adrenergic receptor to different $\mathrm{G}$ proteins by protein kinase A. Nature 390(6655):88-91

daCosta CJ, Baenziger JE (2013) Gating of pentameric ligand-gated ion channels: structural insights and ambiguities. Structure 21(8):1271-1283

Davis TL, Sharif NA (1999) Quantitative autoradiographic visualization and pharmacology of FP-prostaglandin receptors in human eyes using the novel phosphor-imaging technology. J Ocul Pharmacol Ther 15(4):323-336

Davuluri G, Espina V, Petricoin EF 3rd, Ross M, Deng J, Liotta LA, Glaser BM (2009) Activated VEGF receptor shed into the vitreous in eyes with wet AMD: a new class of biomarkers in the vitreous with potential for predicting the treatment timing and monitoring response. Arch Ophthalmol 127(5):613-621

Dismuke WM, Mbadugha CC, Ellis DZ (2008) NO-induced regulation of human trabecular meshwork cell volume and aqueous humor outflow facility involve the $\mathrm{BKCa}$ ion channel. Am J Physiol Cell Physiol 294(6):C1378-C1386

Dumont DJ, Jussila L, Taipale J, Lymboussaki A, Mustonen T, Pajusola K, Breitman M, Alitalo K (1998) Cardiovascular failure in mouse embryos deficient in VEGF receptor-3. Science 282 (5390):946-949

Ehinger B (1964) Distribution of adrenergic nerves to orbital structures. Acta Physiol Scand 62:291-292

Elena PP, Kosina-Boix M, Moulin G, Lapalus P (1987) Autoradiographic localization of betaadrenergic receptors in rabbit eye. Invest Ophthalmol Vis Sci 28(8):1436-1441

Ellis DZ, Nathanson JA, Rabe J, Sweadner KJ (2001) Carbachol and nitric oxide inhibition of Na, K-ATPase activity in bovine ciliary processes. Invest Ophthalmol Vis Sci 42(11):2625-2631

Ferrari-Dileo G (1988) Beta 1 and beta 2 adrenergic binding sites in bovine retina and retinal blood vessels. Invest Ophthalmol Vis Sci 29(5):695-699

Fong GH, Rossant J, Gertsenstein M, Breitman ML (1995) Role of the Flt-1 receptor tyrosine kinase in regulating the assembly of vascular endothelium. Nature 376(6535):66-70 
Foureaux G, Nogueira JC, Nogueira BS, Fulgêncio GO, Menezes GB, Fernandes SOA, Cardoso VN, Fernandes RS, Oliveira GP, Franca JR et al (2013) Antiglaucomatous effects of the activation of intrinsic angiotensin-converting enzyme 2. Invest Ophthalmol Vis Sci 54 (6):4296-4306

Fu Q, Kim S, Soto D, De Arcangelis V, DiPilato L, Liu S, Xu B, Shi Q, Zhang J, Xiang YK (2014) A long lasting $\beta 1$ adrenergic receptor stimulation of cAMP/protein kinase A (PKA) signal in cardiac myocytes. J Biol Chem 289(21):14771-14781

Gao H, Qiao X, Cantor LB, WuDunn D (2002) Up-regulation of brain-derived neurotrophic factor expression by brimonidine in rat retinal ganglion cells. Arch Ophthalmol 120(6):797-803

Garcia-Hoyos M, Auz-Alexandre CL, Almoguera B, Cantalapiedra D, Riveiro-Alvarez R, LopezMartinez MA, Gimenez A, Blanco-Kelly F, Avila-Fernandez A, Trujillo-Tiebas MJ et al (2011) Mutation analysis at codon 838 of the Guanylate Cyclase 2D gene in Spanish families with autosomal dominant cone, cone-rod, and macular dystrophies. Mol Vis 17:1103-1109

Germain P, Staels B, Dacquet C, Spedding M, Laudet V (2006) Overview of nomenclature of nuclear receptors. Pharmacol Rev 58(4):685-704

Gileadi O (2014) Structures of soluble guanylate cyclase: implications for regulatory mechanisms and drug development. Biochem Soc Trans 42(1):108-113

Gilger BC, Wilkie DA, Salmon JH, Peel MR (2013) A topical aqueous calcineurin inhibitor for the treatment of naturally occurring keratoconjunctivitis sicca in dogs. Vet Ophthalmol 16 (3):192-197

Hara S, Hazama A, Miyake M, Kojima T, Sasaki Y, Shimazaki J, Dogru M, Tsubota K (2010) The effect of topical amiloride eye drops on tear quantity in rabbits. Mol Vis 16:2279-2285

Hayashi A, Imai K, Kim HC, and de Juan E, Jr. (1997) Activation of protein tyrosine phosphorylation after retinal branch vein occlusion in cats. Invest Ophthalmol Vis Sci 38(2):372-380

Heier JS, Brown DM, Chong V, Korobelnik JF, Kaiser PK, Nguyen QD, Kirchhof B, Ho A, Ogura Y, Yancopoulos GD et al (2012) Intravitreal aflibercept (VEGF trap-eye) in wet age-related macular degeneration. Ophthalmology 119(12):2537-2548

Hinck AP (2012) Structural studies of the TGF-betas and their receptors - insights into evolution of the TGF-beta superfamily. FEBS Lett 586(14):1860-1870

Hiratsuka S, Minowa O, Kuno J, Noda T, Shibuya M (1998) Flt-1 lacking the tyrosine kinase domain is sufficient for normal development and angiogenesis in mice. Proc Natl Acad Sci U S A 95(16):9349-9354

Huang Y, Gil DW, Vanscheeuwijck P, Stamer WD, Regan JW (1995) Localization of alpha 2-adrenergic receptor subtypes in the anterior segment of the human eye with selective antibodies. Invest Ophthalmol Vis Sci 36(13):2729-2739

Izushi K, Nakahara H, Tai N, Mio M, Watanabe T, Kamei C (2002) The role of histamine H (1) receptors in late-phase reaction of allergic conjunctivitis. Eur J Pharmacol 440(1):79-82

Jampel HD, Lynch MG, Brown RH, Kuhar MJ, De Souza EB (1987) Beta-adrenergic receptors in human trabecular meshwork. Identification and autoradiographic localization. Invest Ophthalmol Vis Sci 28(5):772-779

Jin Y, Verstappen A, Yorio T (1994) Characterization of alpha 2-adrenoceptor binding sites in rabbit ciliary body membranes. Invest Ophthalmol Vis Sci 35(5):2500-2508

Johnston CA, Siderovski DP (2007) Receptor-mediated activation of heterotrimeric G-proteins: current structural insights. Mol Pharmacol 72(2):219-230

Kanamori A, Naka M, Fukuda M, Nakamura M, Negi A (2009) Latanoprost protects rat retinal ganglion cells from apoptosis in vitro and in vivo. Exp Eye Res 88(3):535-541

Kapoor KG, Mirza SN, Gonzales JA, Gibran SK (2010) Visual loss associated with tacrolimus: case report and review of the literature. Cutan Ocul Toxicol 29(2):137-139

Kaswan RL, Salisbury M, Ward DA (1989) Spontaneous canine keratoconjunctivitis sicca: a useful model for human keratoconjunctivitis sicca: treatment with cyclosporine eye drops. Arch Ophthalmol 107(8):1210-1216 
Katritch V, Cherezov V, Stevens RC (2013) Structure-function of the G protein-coupled receptor superfamily. Annu Rev Pharmacol Toxicol 53:531-556

Kim I, Ryan AM, Rohan R, Amano S, Agular S, Miller JW, Adamis AP (1999) Constitutive expression of VEGF, VEGFR-1, and VEGFR-2 in normal eyes. Invest Ophthalmol Vis Sci 40 (9):2115-2121

Kirkegaard J, Secher C, Mygind N (1982) Effect of the H1 antihistamine chlorpheniramine maleate on histamine-induced symptoms in the human conjunctiva. Indirect evidence for nervous H1 receptors. Allergy 37(3):203-208

Kliffen M, Sharma HS, Mooy CM, Kerkvliet S, de Jong PT (1997) Increased expression of angiogenic growth factors in age-related maculopathy. Br J Ophthalmol 81(2):154-162

Kobilka BK (2007) G protein coupled receptor structure and activation. Biochim Biophys Acta 1768(4):794-807

Krishnamoorthy RR, Rao VR, Dauphin R, Prasanna G, Johnson C, Yorio T (2008) Role of the ETB receptor in retinal ganglion cell death in glaucoma. Can J Physiol Pharmacol 86 (6):380-393

Krueger B, Schlotzer-Schrehardt U, Haerteis S, Zenkel M, Chankiewitz VE, Amann KU, Kruse FE, Korbmacher C (2012) Four subunits (alphabetagammadelta) of the epithelial sodium channel $(\mathrm{ENaC})$ are expressed in the human eye in various locations. Invest Ophthalmol Vis Sci 53(2):596-604

Krzystolik MG, Afshari MA, Adamis AP et al (2002) Prevention of experimental choroidal neovascularization with intravitreal anti-vascular endothelial growth factor antibody fragment. Arch Ophthalmol 120(3):338-346

Kvanta A, Algvere PV, Berglin L, Seregard S (1996) Subfoveal fibrovascular membranes in age-related macular degeneration express vascular endothelial growth factor. Invest Ophthalmol Vis Sci 37(9):1929-1934

Lahav M, Melamed E, Dafna Z, Atlas D (1978) Localization of beta receptors in the anterior segment of the rat eye by a fluorescent analogue of propranolol. Invest Ophthalmol Vis Sci 17 (7):645-651

Larson T, Nussenblatt RB, Sen HN (2011) Emerging drugs for uveitis. Expert Opin Emerg Drugs 16(2):309-322

Le Novere N, Changeux JP (2001) LGICdb: the ligand-gated ion channel database. Nucleic Acids Res 29(1):294-295

Lemmon MA, Schlessinger J (2010) Cell signaling by receptor tyrosine kinases. Cell 141 (7):1117-1134

Lemoine D, Jiang R, Taly A, Chataigneau T, Specht A, Grutter T (2012) Ligand-gated ion channels: new insights into neurological disorders and ligand recognition. Chem Rev 112 (12):6285-6318

Leonardi A, Di Stefano A, Vicari C, Motterle L, Brun P (2011) Histamine H4 receptors in normal conjunctiva and in vernal keratoconjunctivitis. Allergy 66(10):1360-1366

Littler E, Stuart AD, Chee MS (1992) Human cytomegalovirus UL97 open reading frame encodes a protein that phosphorylates the antiviral nucleoside analogue ganciclovir. Nature 358 (6382):160-162

Losel RM, Falkenstein E, Feuring M, Schultz A, Tillmann HC, Rossol-Haseroth K, Wehling M (2003) Nongenomic steroid action: controversies, questions, and answers. Physiol Rev 83 (3):965-1016

Maren TH, Conroy CW (1993) A new class of carbonic anhydrase inhibitor. J Biol Chem 268 (35):26233-26239

Matsuo T, Cynader MS (1992) Localisation of prostaglandin F2 alpha and E2 binding sites in the human eye. Br J Ophthalmol 76(4):210-213

Mayer ML (2005) Glutamate receptor ion channels. Curr Opin Neurobiol 15(3):282-288

McCabe CF, McCabe SE (2012) Comparative efficacy of bepotastine besilate 1.5\% ophthalmic solution versus olopatadine hydrochloride $0.2 \%$ ophthalmic solution evaluated by patient preference. Clin Ophthalmol (Auckland, NZ) 6:1731-1738 
Miller JW, Adamis AP, Shima DT, D'Amore PA, Moulton RS, O'Reilly MS, Folkman J, Dvorak HF, Brown LF, Berse B et al (1994) Vascular endothelial growth factor/vascular permeability factor is temporally and spatially correlated with ocular angiogenesis in a primate model. Am J Pathol 145(3):574-584

Mittag TW, Tormay A, Severin C, Podos SM (1985) Alpha-adrenergic antagonists: correlation of the effect on intraocular pressure and on $\alpha 2$-adrenergic receptor binding specificity in the rabbit eye. Exp Eye Res 40(4):591-599

Mueller BH 2nd, Park Y, Daudt DR 3rd, Ma HY, Akopova I, Stankowska DL, Clark AF, Yorio T (2013) Sigma-1 receptor stimulation attenuates calcium influx through activated L-type voltage gated calcium channels in purified retinal ganglion cells. Exp Eye Res 107:21-31

Mueller BH 2nd, Park Y, Ma HY, Dibas A, Ellis DZ, Clark AF, Yorio T (2014) Sigma-1 receptor stimulation protects retinal ganglion cells from ischemia-like insult through the activation of extracellular-signal-regulated kinases 1/2. Exp Eye Res 128:156-169

Nathanson JA (1980) Adrenergic regulation of intraocular pressure: identification of beta 2-adrenergic-stimulated adenylate cyclase in ciliary process epithelium. Proc Natl Acad Sci U S A 77 (12):7420-7424

Neufeld AH, Zawistowski KA, Page ED, Bromberg BB (1978) Influences on the density of betaadrenergic receptors in the cornea and iris-ciliary body of the rabbit. Invest Ophthalmol Vis Sci 17(11):1069-1075

Nguyen QD, Shah SM, Hafiz G, Quinlan E, Sung J, Chu K, Cedarbaum JM, Campochiaro PA (2006) A phase I trial of an IV-administered vascular endothelial growth factor trap for treatment in patients with choroidal neovascularization due to age-related macular degeneration. Ophthalmology 113(9):1522 e1521-1522 e1514

Nussenblatt RB, Fortin E, Schiffman R, Rizzo L, Smith J, Van Veldhuisen P, Sran P, Yaffe A, Goldman CK, Waldmann TA et al (1999) Treatment of noninfectious intermediate and posterior uveitis with the humanized anti-Tac mAb: a phase I/II clinical trial. Proc Natl Acad Sci U S A 96(13):7462-7466

O'Brien TP (2003) Management of bacterial keratitis: beyond exorcism towards consideration of organism and host factors. Eye 17(8):957-974

Ocklind A, Lake S, Wentzel P, Nister M, Stjernschantz J (1996) Localization of the prostaglandin F2 alpha receptor messenger RNA and protein in the cynomolgus monkey eye. Invest Ophthalmol Vis Sci 37(5):716-726

Ogidigben M, Chu TC, Potter DE (1994) Alpha-2 adrenoceptor mediated changes in aqueous dynamics: effect of pertussis toxin. Exp Eye Res 58(6):729-736

Okada T, Ernst OP, Palczewski K, Hofmann KP (2001) Activation of rhodopsin: new insights from structural and biochemical studies. Trends Biochem Sci 26(5):318-324

Okayama Y, Benyon RC, Lowman MA, Church MK (1994) In vitro effects of H1-antihistamines on histamine and PGD2 release from mast cells of human lung, tonsil, and skin. Allergy 49 (4):246-253

Oldham WM, Hamm HE (2008) Heterotrimeric G protein activation by G-protein-coupled receptors. Nat Rev Mol Cell Biol 9(1):60-71

Orban T, Jastrzebska B, Palczewski K (2014) Structural approaches to understanding retinal proteins needed for vision. Curr Opin Cell Biol 27:32-43

Ozaki H, Hayashi H, Vinores SA, Moromizato Y, Campochiaro PA, Oshima K (1997) Intravitreal sustained release of VEGF causes retinal neovascularization in rabbits and breakdown of the blood-retinal barrier in rabbits and primates. Exp Eye Res 64(4):505-517

Pankratov Y, Lalo U (2014) Calcium permeability of ligand-gated $\mathrm{Ca}^{2+}$ channels. Eur J Pharmacol 739:60-73

Patel AK, Syeda S, Hackam AS (2013) Signal transducer and activator of transcription 3 (STAT3) signaling in retinal pigment epithelium cells. Jak-Stat 2(4), e25434

Pierce EA, Avery RL, Foley ED, Aiello LP, Smith LE (1995) Vascular endothelial growth factor/ vascular permeability factor expression in a mouse model of retinal neovascularization. Proc Natl Acad Sci U S A 92(3):905-909 
Polman JA, Welten JE, Bosch DS, de Jonge RT, Balog J, van der Maarel SM, de Kloet ER, Datson NA (2012) A genome-wide signature of glucocorticoid receptor binding in neuronal PC12 cells. BMC Neurosci 13:118

Potter DE, Rowland JM (1978) Adrenergic drugs and intraocular pressure: Effects of selective $\beta$-adrenergic agonists. Exp Eye Res 27(6):615-625

Prasanna G, Krishnamoorthy R, Yorio T (2011) Endothelin, astrocytes and glaucoma. Exp Eye Res 93(2):170-177

Quigley HA, Broman AT (2006) The number of people with glaucoma worldwide in 2010 and 2020. Br J Ophthalmol 90(3):262-267

Rosenfeld PJ, Moshfeghi AA, Puliafito CA (2005) Optical coherence tomography findings after an intravitreal injection of bevacizumab (avastin) for neovascular age-related macular degeneration. Ophthalmic Surg Lasers Imaging 36(4):331-335

Rosenfeld PJ, Brown DM, Heier JS, Boyer DS, Kaiser PK, Chung CY, Kim RY (2006) Ranibizumab for neovascular age-related macular degeneration. N Engl J Med 355 (14):1419-1431

Sadikot RT, Blackwell TS, Christman JW, Prince AS (2005) Pathogen-host interactions in Pseudomonas aeruginosa pneumonia. Am J Respir Crit Care Med 171(11):1209-1223

Sanderson J, Dartt DA, Trinkaus-Randall V, Pintor J, Civan MM, Delamere NA, Fletcher EL, Salt TE, Grosche A, Mitchell CH (2014) Purines in the eye: recent evidence for the physiological and pathological role of purines in the RPE, retinal neurons, astrocytes, Muller cells, lens, trabecular meshwork, cornea and lacrimal gland. Exp Eye Res 127:270-279

Schlotzer-Schrehardt U, Zenkel M, Nusing RM (2002) Expression and localization of FP and EP prostanoid receptor subtypes in human ocular tissues. Invest Ophthalmol Vis Sci 43 (5):1475-1487

Sears ML, Sherk TE (1963) Supersensitivity of aqueous outflow resistance in rabbits after sympathetic denervation. Nature 197:387-388

Shalaby F, Rossant J, Yamaguchi TP, Gertsenstein M, Wu XF, Breitman ML, Schuh AC (1995) Failure of blood-island formation and vasculogenesis in Flk-1-deficient mice. Nature 376 (6535):62-66

Sheikh A, Hurwitz B (2001) Topical antibiotics for acute bacterial conjunctivitis: a systematic review. Br J Gen Pract 51(467):473-477

Simon MI, Strathmann MP, Gautam N (1991) Diversity of G proteins in signal transduction. Science 252(5007):802-808

Smith JR, Levinson RD, Holland GN, Jabs DA, Robinson MR, Whitcup SM, Rosenbaum JT (2001) Differential efficacy of tumor necrosis factor inhibition in the management of inflammatory eye disease and associated rheumatic disease. Arthritis Care Res 45(3):252-257

Smith SB, Duplantier J, Dun Y, Mysona B, Roon P, Martin PM, Ganapathy V (2008) In vivo protection against retinal neurodegeneration by sigma receptor 1 ligand (+)-pentazocine. Invest Ophthalmol Vis Sci 49(9):4154-4161

Smrcka AV (2008) G protein betagamma subunits: central mediators of G protein-coupled receptor signaling. Cell Mol Life Sci 65(14):2191-2214

Srinivas SP, Satpathy M, Guo Y, Anandan V (2006) Histamine-induced phosphorylation of the regulatory light chain of myosin II disrupts the barrier integrity of corneal endothelial cells. Invest Ophthalmol Vis Sci 47(9):4011-4018

Starr MS (1971) Further studies on the effect of prostaglandin on intraocular pressure in the rabbit. Exp Eye Res 11(2):170-177

Stone J, Itin A, Alon T, Pe'er J, Gnessin H, Chan-Ling T, Keshet E (1995) Development of retinal vasculature is mediated by hypoxia-induced vascular endothelial growth factor (VEGF) expression by neuroglia. J Neurosci 15(7 Pt 1):4738-4747

Suzuki N, Emura T, Fukushima M (2011) Mode of action of trifluorothymidine (TFT) against DNA replication and repair enzymes. Int J Oncol 39(1):263-270 
ten Tusscher MP, Klooster J, van der Want JJ, Lamers WP, Vrensen GF (1989) The allocation of nerve fibres to the anterior eye segment and peripheral ganglia of rats. II The sympathetic innervation. Brain Res 494(1):105-113

Tezel G, Kass MA, Kolker AE, Becker B, Wax MB (1997) Plasma and aqueous humor endothelin levels in primary open-angle glaucoma. J Glaucoma 6(2):83-89

The Multicenter Uveitis Steroid Treatment Trial Research G, Kempen JH, Altaweel MM, Holbrook JT, Jabs DA, Louis TA, Sugar EA, Thorne JE (2011) Randomized comparison of systemic anti-inflammatory therapy versus fluocinolone acetonide implant for intermediate, posterior and panuveitis: the multicenter uveitis steroid treatment trial. Ophthalmology 118 (10):1916-1926

Toris CB, Gleason ML, Camras CB, Yablonski ME (1995) Effects of brimonidine on aqueous humor dynamics in human eyes. Arch Ophthalmol 113(12):1514-1517

Toris CB, Gabelt BAT, Kaufman PL (2008) Update on the mechanism of action of topical prostaglandins for intraocular pressure reduction. Surv Ophthalmol 53(Suppl 1):S107-S120

Traynelis SF, Wollmuth LP, McBain CJ, Menniti FS, Vance KM, Ogden KK, Hansen KB, Yuan H, Myers SJ, Dingledine R (2010) Glutamate receptor ion channels: structure, regulation, and function. Pharmacol Rev 62(3):405-496

Triantafylla M, Massa HF, Dardabounis D, Gatzioufas Z, Kozobolis V, Ioannakis K, Perente I, Panos GD (2014) Ranibizumab for the treatment of degenerative ocular conditions. Clin Ophthalmol 8:1187-1198

Umemoto M, Tanaka H, Miichi H, Hayashi S (1987) Histamine receptors on rat ocular surface. Ophthalmic Res 19(4):200-204

Vaajanen A, Vapaatalo H (2011) Local ocular renin-angiotensin system - a target for glaucoma therapy? Basic Clin Pharmacol Toxicol 109(4):217-224

van Alphen GW (1976) The adrenergic receptors of the intraocular muscles of the human eye. Invest Ophthalmol 15(6):502-505

van der Valk R, Webers CA, Lumley T, Hendrikse F, Prins MH, Schouten JS (2009) A network meta-analysis combined direct and indirect comparisons between glaucoma drugs to rank effectiveness in lowering intraocular pressure. J Clin Epidemiol 62(12):1279-1283

Waitzman MB, Woods WD (1971) Some characteristics of an adenyl cyclase preparation from rabbit ciliary process tissue. Exp Eye Res 12(1):99-111

Wang RF, Lee PY, Taniguchi T, Becker B, Podos SM, Serle JB, Mittag TW (1993) Effect of oxymetazoline on aqueous humor dynamics and ocular blood flow in monkeys and rabbits. Arch Ophthalmol 111(4):535-538

Wen Y, Edelman JL, Kang T, Zeng N, Sachs G (1998) Two functional forms of vascular endothelial growth factor receptor-2/Flk-1 mRNA are expressed in normal rat retina. J Biol Chem 273(4):2090-2097

Wheeler LA, Gil DW, WoldeMussie E (2001) Role of alpha-2 adrenergic receptors in neuroprotection and glaucoma. Surv Ophthalmol 45(Suppl 3):S290-S294

Wilks AF (1989) Two putative protein-tyrosine kinases identified by application of the polymerase chain reaction. Proc Natl Acad Sci U S A 86(5):1603-1607

Willcox MDP (2011) Review of resistance of ocular isolates of Pseudomonas aeruginosa and staphylococci from keratitis to ciprofloxacin, gentamicin and cephalosporins. Clin Exp Optom 94(2):161-168

Wistrand P (1959) The effect of carbonic anhydrase inhibitor on intra-ocular pressure with observations on the pharmacology of acetazolamide in the rabbit. Acta Pharmacol Toxicol (Copenh) 16:171-193

Witmer AN, Blaauwgeers HG, Weich HA, Alitalo K, Vrensen GF, Schlingemann RO (2002) Altered expression patterns of VEGF receptors in human diabetic retina and in experimental VEGF-induced retinopathy in monkey. Invest Ophthalmol Vis Sci 43(3):849-857

WoldeMussie E, Ruiz G, Wijono M, Wheeler LA (2001) Neuroprotection of retinal ganglion cells by brimonidine in rats with laser-induced chronic ocular hypertension. Invest Ophthalmol Vis Sci 42(12):2849-2855 
Woldemussie E, Wijono M, Pow D (2007) Localization of alpha 2 receptors in ocular tissues. Vis Neurosci 24(5):745-756

Woodward DF, Ledgard SE, Nieves AL (1986) Conjunctival immediate hypersensitivity: re-evaluation of histamine involvement in the vasopermeability response. Invest Ophthalmol Vis Sci 27(1):57-63

Xu HE, Xiao RP (2012) A new era for GPCR research: structures, biology and drug discovery. Acta Pharmacol Sin 33(3):289-290

Yoshida A, Fujihara T, Nakata K (1999) Cyclosporin A Increases Tear Fluid Secretion via Release of Sensory Neurotransmitters and Muscarinic Pathway in Mice. Exp Eye Res 68(5):541-546

Zhang J, Xu K, Ambati B, Yu F-SX (2003) Toll-like Receptor 5-Mediated Corneal Epithelial Inflammatory Responses to Pseudomonas aeruginosa Flagellin. Invest Ophthalmol Vis Sci 44 (10):4247-4254 